\title{
PENGARUH LUAS LAHAN TERHADAP PENDAPATAN USAHATANI SEMANGKA DI DESA CIKADU KECAMATAN CIKALONG KABUPATEN TASIKMALAYA
}

\section{THE EFFECT OF LAND AREA ON INCOME OF WATERMELON FARMERS IN CIKADU VILLAGE, CIKALONG DISTRICT, TASIKMALAYA REGENCY}

\author{
Ane Novianty* ${ }^{1}$, Fitri Awaliyah ${ }^{2}$ \\ ${ }^{1}$ Universitas Galuh, Ciamis \\ ${ }^{2}$ Universitas Garut, Garut \\ *E-mail: noviantyane29@gmail.com
}

(Diterima 27-12-2021; Disetujui 22-01-2022)

\begin{abstract}
ABSTRAK
Lahan merupakan faktor produksi yang paling penting karena balas jasa yang diterima oleh lahan lebih tinggi dibandingkan dengan faktor produksi yang lain. Semakin menyempitnya kepemilikan lahan, menyebabkan kesempatan petani memperoleh keuntungan yang tinggi semakin kecil. Penelitian ini bertujuan untuk menganalisis tingkat pengaruh luas lahan terhadap pendapatan usahatani semangka di Desa Cikadu Kecamatan Cikalong Kabupaten Tasikmalaya. Penelitian dilakukan dengan studi kasus pada 10 petani semangka, dengan variabel yang digunakan yaitu luas lahan dan pendapatan usahatani. Berdasarkan analisis koefisien determinasi, diketahui besarnya pengaruh luas lahan terhadap pendapatan usahatani sebesar $87,42 \%$ yang artinya luas lahan mampu mempengaruhi pendapatan usahatani sebesar $87,42 \%$ dan sisanya dipengaruhi oleh variabel lain. Selanjutnya hasil analisis linier sederhana menunjukkan nilai $t$ hitung 7,487 $>\mathrm{t}$ tabel 2,306 yang berarti, luas lahan mempunya pengaruh yang positif dan signifikan terhadap pendapatan usahatani semangka.
\end{abstract}

Kata kunci: Luas Lahan, Pendapatan, Pengaruh, Usahatani Semangka

\section{ABSTRACT}

The land is the most important factor of production because the remuneration received by land is higher than other factors of production. The narrowing of land ownership, causing farmers to get smaller profits. This study aims to analyze the effect of land area on watermelon farming income in Cikadu Village, Cikalong District, Tasikmalaya Regency. The research was conducted by a case study on 10 watermelon farmers, with the variables used being land area $(X)$ and farm income $(Y)$. Based on the coefficient of determination analysis, it is known that the influence of land area on farming is $87.42 \%$, which means that land area can affect farm income by $87.42 \%$ and its effect on other variables. Furthermore, the results of the linear analysis showed the value of $t$ arithmetic $7.487>t$ table 2.306 which means, land area has a positive and significant influence on the income of watermelon farming.

Keywords: Land Area, Income, Influence, Watermelon Farming

\section{PENDAHULUAN}

Sektor pertanian merupakan salah satu sektor penting di setiap negara dalam menunjang kehidupan sosial dan ekonomi dari masyarakat di negara tersebut. Tanpa meniadakan peranan penting dari perbankan, industri dan jasa hiburan dalam perkembangan suatu 
daerah atau kota, sektor pertanian memberikan kontribusi yang penting dalam perkembangan suatu masyarakat, sehubungan dengan ketersediaan bahan pangan yang dibutuhkan oleh setiap orang dalam melakukan aktifitas pribadi dan sosial (Tamalonggehe dkk, 2015). Selain menyediakan kebutuhan pangan, sektor pertanian berperan dalam menampung jumlah penduduk serta memberikan kesempatan untuk bekerja kepada setiap penduduk, menciptakan pendapatan secara nasional sehingga dapat menurunkan angka kemiskinan (Umaruddin dan Juliyani, 2018). Sesuai dengan pernyataan Nguyen et.al (2015), peran sektor pertanian di negara berkembang yaitu sebagai sumber pendapatan para pekerja dengan estimasi 60 sampai 70 persen.

Pendapatan bisa digunakan sebagai alat untuk mengukur kondisi ekonomi seseorang, dimana pendapatan tersebut dapat digunakan untuk memenuhi kebutuhan hidup dan kelangsungan suatu usaha. Pendapatan menunjukkan seluruh uang yang dihasilkan dari penggunaan kekayaan atau jasa yang diterima oleh seseorang selama jangka waktu tertentu pada suatu kegiatan ekonomi (I Gusti dan Cipta, 2021). Pendapatan yang didapatkan dari usahatani merupakan hasil dari pengelolaan faktor-faktor produksi. Salah satu faktor produksi usahatani adalah lahan.

Negara agraris seperti Indonesia, lahan merupakan faktor produksi yang paling penting dibandingkan dengan faktor produksi lain karena balas jasa yang diterima oleh lahan lebih tinggi dibandingkan dengan faktor produksi yang lain. Luas lahan pertanian mempengaruhi skala usahatani yang pada akhirnya mempengaruhi tingkat efisiensi suatu usahatani yang dijalankan (I Nyoman dan Wardana, 2018). Mubyarto (1989) menyatakan bahwa, lahan adalah salah satu faktor produksi, tempat dihasilkannya produk pertanian yang memiliki sumbangan yang cukup besar terhadap usahatani, karena banyak sedikitnya hasil produksi dari usahatani sangat dipengaruhi oleh luas sempitnya lahan yang digunakan.

Permasalahan yang terjadi saat ini adalah kepemilikan lahan yang semakin menyempit akibat adanya pertumbuhan penduduk yang tinggi. Lahan pertanian yang ada terbagi-bagi menurut anggota keluarga yang dimiliki oleh para keluarga tani (Asri dkk, 2012). Kondisi demikian cenderung mengharuskan petani memilih jenis tanaman yang lebih menguntungkan dan mempunyai nilai ekonomi tinggi. 
Salah satu komoditas yang potensial untuk dikembangkan adalah semangka.

Sebagai komoditas potensial yang dapat dikembangkan, menjadi daya tarik bagi beberapa petani di Desa Cikadu Kecamatan Cikalong Kabupaten Tasikmalaya untuk membudidayakan semangka. Selain bernilai ekonomi tinggi, menurut Rukmana (2005) dalam Edi dan Mayangsari (2019) beberapa kelebihan usahatani semangka diantaranya adalah berumur relatif singkat hanya sekitar $70-80$ hari, dan mudah dipraktekkan para petani dengan cara konvensional maupun semi intensif. Julkifli dkk (2019) menyatakan bahwa, buah semangka berkualitas baik telah banyak dipasarkan di supermarket di kota-kota besar dengan pelanggan yang merupakan masyarakat golongan ekonomi menengah ke atas. Kondisi demikian menjadikan permintaan pasar buah semangka semakin meningkat. Terlebih pada saat hasil panen semangka dari daerah-daerah penghasilnya menurun, menyebabkan harga melonjak beberapa kali lipat.

Peluang strategis bagi pelaku
usahatani dalam meningkatkan
pendapatan adalah ketika mampu
memenuhi permintaan pasar potensial
sesuai dengan "kapan" dan "dimana"

barang tersebut dibutuhkan dalam tingkat harga yang relatif tinggi. Bagi beberapa petani semangka di Desa Cikadu yang memiliki keterbatasan lahan, kesempatan dan stabilitas produksi merupakan indikator yang perlu dicermati agar dapat menghasilkan pendapatan yang relatif tinggi. Berdasarkan uraian permasalahan di atas, penelitian ini bertujuan untuk mengetahui "Pengaruh Luas Lahan Terhadap Usahatani Semangka di Desa Cikadu Kecamatan Cikalong Kabupaten Tasikmalaya".

\section{METODE PENELITIAN}

Jenis penelitian yang digunakan adalah studi kasus pada petani semangka di Desa Cikadu Kecamatan Cikalong Kabupaten Tasikmalaya. Menurut Rahardjo dan Gudnanto (2011), studi kasus merupakan metode yang diterapkan untuk memahami individu lebih mendalam dengan dipraktekan secara integratif dan komprehensif. Pengambilan data dilakukan pada seluruh petani semangka di Desa Cikadu sebanyak 10 orang petani.

Penelitian ini menggunakan dua variabel yaitu variabel independen dan variabel dependen. Variabel dependen dalam penelitian ini adalah pendapatan usahatani (Y) dan variabel independen 
yang diamati adalah luas lahan (X). Langkah-langkah yang perlu dilakukan untuk mengetahui pengaruh luas lahan terhadap pendapatan adalah menentukan skala pengukuran. Skala pengukuran merupakan seperangkat aturan yang diperlukan untuk mengkuantifitatifkan data dari pengukuran suatu variabel (Febtriko, 2017).

Variabel dalam penelitian ini diukur menggunakan skala rasio, dimana skala rasio merupakan tingkat pengukuran tertinggi karena memberikan nilai absolut pada data/objek yang akan diukur. Selanjutnya kedua variabel tersebut diuji dengan analisis regresi linear sederhana.

\section{HASIL DAN PEMBAHASAN}

\section{Gambaran Umum Lokasi Penelitian}

Desa Cikadu merupakan salah satu dari 13 Desa di Wilayah Kecamatan Cikalong Kabupaten Tasikmalaya yang memiliki luas wilayah $972.028 \mathrm{Ha}$. Sebagian besar lahan di wilayah Desa Cikadu dipergunakan sebagai lahan hutan dan lahan pertanian $68 \%$, selanjutnya wilayah pemukiman sebesar 32,47\%, serta fasilitas umum dan sosial dengan presentase terendah yaitu $7,6 \%$. Gambaran penggunaan lahan tersebut dapat menunjukkan identitas suatu wilayah bahwa sebagian besar penduduknya bermata pencaharian sebagai petani. Besarnya penggunaan lahan untuk pertanian di Desa Cikadu dapat menjadi sumber pendapatan potensial bagi penduduknya, tinggal bagaimana masing-masing petani mengoptimalkan penggunaan lahan secara efektif dan efisien.

\section{Identitas Responden}

Petani semangka di Desa Cikadu rata-rata tergolong usia produktif yaitu antara 41 sampai dengan 64 tahun. Pengalaman berusahatani semangka yang bervariasi antara 2 hingga 8 tahun dengan latar belakang pendidikan yang tergolong rendah. Luas lahan yang diusahakan tergolong sempit dengan rata-rata kepemilikan lahan seluas 0,819 ha dengan rata-rata pendapatan yang mampu dihasilkan sebesar Rp 16.968.141/MT.

\section{Analisis Pengaruh Luas Lahan} Terhadap Pendapatan Usahatani

Data klasifikasi kontinu, data kuantitatif yang termasuk dalam pengukuran data skala interval atau rasio, untuk dapat dilakukan uji statistik parametrik dipersyaratkan berdistribusi normal. Pembuktian data berdistribusi 
normal tersebut perlu dilakukan uji normalitas terhadap data. Uji normalitas berguna untuk membuktikan data dari sampel yang dimiliki berasal dari populasi berdistribusi normal atau data populasi yang dimiliki berdistribusi normal.

\section{Uji Normalitas}

Data klasifikasi kontinu, data kuantitatif yang termasuk dalam pengukuran data skala interval atau rasio, untuk dapat dilakukan uji statistik parametrik dipersyaratkan berdistribusi normal. Pembuktian data berdistribusi normal tersebut perlu dilakukan uji normalitas terhadap data. Uji normalitas berguna untuk membuktikan data dari sampel yang dimiliki berasal dari populasi berdistribusi normal atau data populasi yang dimiliki berdistribusi normal.

Tabel 1. Hasil Uji Normalitas Data

\begin{tabular}{lr} 
& Unstandardized Residual \\
\hline $\mathrm{N}$ & 10 \\
Kolmogorov- & \\
Smirnov Z & .499 \\
$\begin{array}{l}\text { Asymp. Sig. (2- } \\
\text { tailed) }\end{array}$ & .965 \\
\hline
\end{tabular}

Sumber: Analisis Data Primer, 2021

Berdasarkan Tabel 1 nilai signifikansi untuk uji normalitas sebesar 0,965, nilai ini lebih besar dari $\alpha 0,05$ sehingga data penelitian dari sampel sebanyak 10 orang berdistribusi normal dan memenuhi prasyarat uji asumsi klasik. Sesuai dengan pernyataan Mitha dan Notobroto (2014), jika data berdistribusi normal maka statistik parametrik dapat digunakan.

\section{Koefisien Determinasi (Kd)}

Koefisien determinasi (Kd) pada intinya mengukur seberapa jauh kemampuan model dalam menerangkan variasi variabel bebas. Besarnya pengaruh luas lahan terhadap pendapatan usahatani ditunjukan pada tabel berikut

Tabel 2. Koefisien Determinasi Luas Lahan Terhadap Pendapatan Usahatani

\begin{tabular}{ccc}
\hline Nilai $r$ & Nilai $^{2}$ & $\begin{array}{c}\text { Koefisien } \\
\text { Determinasi }\end{array}$ \\
\hline 0,935 & 0,8742 & $87,42 \%$ \\
\hline
\end{tabular}

Sumber: Analisis Data Primer, 2021

Berdasarkan tabel tersebut diketahui besarnya pengaruh luas lahan terhadap pendapatan usahatani sebesar $87,42 \%$ yang diperoleh dari koefisien korelasi parsial luas lahan di kuadratkan yaitu $(0,935)^{2}$ x $100 \%$. Artinya variabel luas lahan mampu mempengaruhi pendapatan usahatani sebesar $87,42 \%$ dan sisanya dipengaruhi oleh variabel lain.

\section{Regresi Linear Sederhana}

Analisis regresi linier sederhana adalah hubungan secara linier antara variabel independen $(\mathrm{X})$ dengan variabel 
dependen (Y). Analisis ini digunakan untuk mengetahui arah hubungan antar variabel. $\mathrm{H}_{0}$ (hipotesis nol) dan $\mathrm{H}_{1}$ (hipotesis alternatif dalam pengujian koefisien regresi linier sederhana untuk variabel luas lahan dan pendapatan usahatani dapat dilakukan dengan rumusan hipotesis sebagai berikut:

$\begin{array}{rlr}\mathrm{H}_{0}: \beta_{1}=0 & \begin{array}{l}\text { Berarti Luas Lahan tidak } \\ \text { berpengaruh } \\ \text { signifikan } \\ \text { terhadap } \\ \text { Usahatani. }\end{array} \\ \mathrm{H}_{1}: \beta_{1} \neq 0 \quad \text { Bendapatan } \\ & \text { berpengaruh signifikan } \\ & \text { terhadap } \\ & \text { Usahatani }\end{array}$

Tabel 3. Hasil Pengujian Pengaruh Luas Lahan Terhadap Pendapatan Usahatani

\begin{tabular}{|c|c|c|c|c|c|}
\hline & Unstandardized & Coefficients & $\begin{array}{l}\text { Standardized } \\
\text { Coefficients }\end{array}$ & t hitung & $\mathrm{t}$ tabel \\
\hline Model & $\mathrm{B}$ & Std. Error & Beta & & \\
\hline 1 (Constant) & 7,615 & 1,270 & & 5,994 & \\
\hline Luas Lahan & 1,142 & 1,525 & 0,935 & 7,487 & 2,306 \\
\hline
\end{tabular}

Sumber: Analisis Data Primer, 2021

$\boldsymbol{\beta 1}=\mathbf{7 , 4 8 7}$ Artinya jika variabel luas lahan naik sebanyak satu satuan maka akan menaikkan pendapatan usahatani sebesar 7,487 satuan. Sebaliknya jika variabel luas lahan turun sebanyak satu satuan maka akan menurunkan pendapatan usahatani sebesar 7,487 satuan.

Selanjutnya untuk dapat menginterpretasikan nilai $t$ yang diperoleh pada Tabel 3, pertama yang harus ditentukan adalah menentukan nilai degree of freedom $(\mathrm{df})$ dengan rumus $\mathrm{df}$ $=(\mathrm{n}-\mathrm{k})$. Sehingga dari total sampel sebanyak 10 orang dapat ditentukan nilai df yaitu 8. Kemudian alpha yang digunakan sebesar $5 \%$ atau $\alpha \quad 0,05$ sehingga didapatkan nilai $t$ tabel sebesar
2,306. Nilai t hitung 7,487 $>\mathrm{t}$ tabel 2,306 maka $\mathrm{H}_{0}$ ditolak. Berarti luas lahan berpengaruh signifikan dan positif terhadap pendapatan usahatani dan ini berarti, jika petani semangka ingin meningkatkan pendapatan usahataninya dapat dilakukan dengan penambahan luas lahan.

Luas lahan berpengaruh terhadap pendapatan usahatani salah satunya berkaitan dengan kesempatan pemenuhan permintaan konsumen. Semakin sempit luas lahan yang dimiliki, semakin kecil kesempatan bagi petani untuk memenuhi permintaan pasar secara maksimal dan kontinu.

Rata-rata tingkat konsumsi semangka perkapita sebesar $13,13 \%$ per 
tahun dan tingkat penyediaan semangka per kapita hanya mencapai $7,59 \%$ per tahun (Badan Statistik Konsumsi Pangan, 2015 dalam Ayu dkk, 2021). Hal ini menyebabkan kurangnya tingkat penyediaan semangka di Indonesia. Padahal, semangka sering dikonsumsi sebagai makanan penutup, makanan ringan, salad, makanan sarapan, makanan piknik, diminum, dan digunakan dalam banyak cara kreatif lainnya (Ibnu dkk, 2016).

Berdasarkan fakta tersebut, ekstensifikasi lahan usahatani merupakan salah satu cara yang dapat dilakukan petani semangka untuk meningkatkan kesempatan produksi guna memenuhi permintaan pasar yang masih sangat tinggi. Namun, lahan yang ada di Desa Cikadu tidak hanya dimanfaatkan untuk aktivitas pertanian, tetapi juga aktivitas non pertanian dan permukiman. Hal ini menjadi tantangan bagi petani semangka untuk menambah luas lahan di Desa Cikadu. Selain karena alih fungsi lahan pertanian yang tidak dapat dihindari karena kebutuhan lahan non pertanian (Ye dan Ranst, 2008), juga terdapat tekanan penduduk terhadap lahan di sektor pertanian. Menurut Ruhimat (2015), tekanan penduduk adalah dorongan terhadap penduduk, khususnya penduduk petani untuk memperluas lahan garapannya atau keluar dari lapangan kerja pertanian.

Walaupun demikian, masih ada faktor-faktor lain yang perlu dipertimbangkan untuk meningkatkan pendapatan usahatani semangka selain menambah luas lahan. Sesuai dengan hasil penelitian yang dilakukan Halimatus dkk (2021) bahwa luas lahan, benih, pupuk, pestisida, dan tenaga kerja merupakan faktor-faktor yang dapat mempengaruhi pendapatan usahatani semangka.

\section{KESIMPULAN DAN SARAN}

Hasil pengujian hipotesis menunjukkan nilai $\mathrm{t}$ hitung 7,487 $>\mathrm{t}$ tabel 2,306 maka $\mathrm{H}_{0}$ ditolak. Berarti luas lahan berpengaruh signifikan dan positif terhadap pendapatan usahatani. Berdasarkan hasil tersebut disarankan kepada petani untuk melakukan upaya ekstensifikasi lahan ataupun upaya lainnya seperti intensifikasi dengan teknologi, guna memenuhi permintaan konsumen yang akhirnya dapat meningkatkan pendapatan usahatani.

\section{DAFTAR PUSTAKA}

Ayu, C.A., Agus, S dan Ruslanjari, D. 2012. Studi Komparatif Pendapatan Petani Semangka dan Petani Padi 
(Studi Kasus Desa Pilang dan Desa Sidodadi Kecamatan Masaran Kabupaten Sragen). Jurnal Bumi Indonesia, 1(3): 156-162.

Ayu, H.D., Marhawati, Mustari, Tuti. S dan Rahmatullah. 2021. Analisis Faktor-Faktor yang Memengaruhi Produksi Semangka di Desa Mangkoso Kecamatan Soppeng Riaja Kabupaten Barru. Journal of Social Sciences and Humanities, 1(1): $1-7$.

Edi, M dan Mayangsari, A. 2019. Analisis Kelayakan Usahatani Semangka (Studi Kasus di Desa Jangkar, Kecamatan Jangkar, Kabupaten Situbondo). Agribios, 17(2): $65-71$.

Febtriko, A. 2017. Pemakaian Mobile Robot dalam Meningkatkan Perkembangan Kognitif Anak Usia Dini di Taman Kanak-Kanak. Jurnal Teknologi dan Sistem Informasi Univrab 2(2): 125-135.

Ghozali, I. 2011. Aplikasi Analisis Multivariate dengan Program SPSS. Semarang: Badan Penerbit Universitas Diponegoro.

Halimatus, S., Ida, E dan Isdiantoni. 2021. Faktor-Faktor yang Mempengaruhi Produksi Usahatani Semangka di Lahan Kering Pulau Poteran. Jurnal Pertanian Cemara, 18(1): $84-93$.

I Gusti, B,A,P dan Cipta, W. 2021. Pengaruh Luas Lahan, Modal dan Jumlah Produksi Terhadap Pendapatan Petani Sayur di Kecamatan Baturiti. Jurnal Ekuitas, 9(1): 93-100.

I Nyoman, A.F.S dan Wardana, I.G. 2018. Pengaruh Luas Lahan,
Alokasi Waktu dan Produksi Petani Terhadap Pendapatan. E-Jurnal EP Unud, 7(9): 2038-2070.

Ibnu, M.R., Kusnandar dan Marwanti, S. 2016. Analisis Faktor-Faktor yang Mempengaruhi Permintaan Semangka di Kecamatan Baki Kabupaten Sukoharjo. Agrista, 4(3): $13-23$.

Julkifli, Maleha, dan Rajudinnor. Analisis Permintaan Buah Semangka di Kota Palangkaraya. Journal Socio Economics Agricultural, 14(1): 29 -37 .

Mitha, A.O dan Notobroto, H.B. 2014. Perbandingan Tingkat Konsistensi Normalitas Distribusi Metode Kolmogorov-Smirnov, Lilliefors, Shapiro-Wilk, dan SkewnesKurtosis. Jurnal Biometrika dan Kependudukan, 3(2): 127-135.

Mubyarto. 1989. Pengantar Ekonomi Pertanian. Jakarta: LP3ES.

Nguyen, A.T., Janet, D \& Andrew, N. 2015. Does Contract Farming Improve Productivity and Income of Farmers ? A Review of Theory and Evidence. The Journal of Developing Areas, 49(6): 531-538.

Ruhimat, M. 2015. Tekanan Penduduk Terhadap Lahan di Kecamatan Sukaraja Kabupaten Sukabumi. Jurnal Pendidikan Geografi, 15(2): $59-65$.

Tamalonggehe, D., Antonius, L dan Maramis, M. 2015. Pengaruh Luas Lahan dan Harga Produksi Terhadap Produksi Tanaman Salak di Kabupaten Sitaro (Studi Kasus Kecamatan Tagulandang). Jurnal Efisiensi, 15(1): 197- 207. 
Umaruddin, U dan Juliani. 2018. Pengaruh Luas Lahan, Pupuk dan Jumlah Tenaga Kerja Terhadap Produksi Padi Gampong Matang Balqi. Jurnal Ekonomi Pertanian Unimal, (1(1): 31-39.
Ye, L dan Ranst, E .V. 2008. Population Carrying Capacity and Sustainabel Agricultural Use of Land Resources in Caoxian Country (North China). Journal of Sustainable Agriculture, $75-94$. 